\title{
From the perfect competition to the Coasian Nature of the Firm
}

\author{
Sónia de Carvalho \\ Assistant Professor at Portucalense Infante D. Henrique University \\ Department of Law \\ Researcher at IJP - Portucalense Institute for Legal Research \\ Porto, Portugal \\ scarvalho@upt.pt
}

\begin{abstract}
The Coasian Nature of the Firm merges neoclassical and institutional economics approaches, by applying the marginal analysis to decision-making processes of the company, with consequences on their structure and size.

This paper aims at drawing the evolution of economic theory from perfect competition model to the Coasian Nature of the Firm, in order to explain the main influences that shaped one of the Transaction Cost Economics underpinnings.
\end{abstract}

Keywords: nature of firm, Ronald Coase, neoclassical theory, perfect competition

\section{INTRODUCTION}

The first manifestations of competition law can be found in the century XVIII, in particular in the work The wealth of nations of Adam Smith, for some considered the father of capitalism and the economy [1].

According to this author, the market was subject to a natural order that is self-regulated. Each individual aims at becoming more efficient than others, in order to overcome the competitors and win more benefits. This selfish spur that encouraged the market players in the pursuit of efficiency would produce as outcome the development of social wealth.

It is in this context that Adam Smith outlines the famous thesis of the invisible hand, able to lead the individual to an end beyond his initial purposes, transforming selfish interests in benefits to society. Despite not having demonstrated that validity of this assertion, Adam Smith assembled a set of measures produced by the disastrous intervention of political power in the market, which until then ruled economic thinking.

It were then seeded the laissez faire, laissez passer roots and the defense of non-interventionism in the economy.

The harmonization between selfish interests and the common interests is ensured by two non-economic forces, moral rules and the legal system, able to address and punish

1 Adam Smith, in Book IV of The Wealth of nations criticized the commercialism and state intervention in economic affairs. Admits, however, the importance of the state's role in maintaining the conditions necessary for the functioning of the competitive process and public work. Adam Smith, Wealth of nations, Kathrin Sutherland ( ed), Oxford University Press, Oxford, 1998 , p. 275 criminals and unfair behavior in the market and economic strength, competition ${ }^{2}$.

The competition is represented as a race for limited products or to drain surplus products, whose purpose is to encourage the discovery of more efficient market behaviors ${ }^{3}$.

Adam Smith, despite the belief in the power of the market to maximize the benefits of competition, was aware that it would be necessary to enforce some political and moral constraints to society to attain the benefits of the free market [2].

Adam Smith, although was not able to identify competition with a market structure, admitted that the market mechanism benefits are dependent on the checks and balances of perfect competition [3].

Later, Malthus and Ricardo, with decisive contributions to the theory and analysis of income, triggered a process, that was concluded by neoclassical theory, through Jevons, Walras and Cournot, towards the transformation of the economic classical theory into an exact science. Competition was, then, described as mathematical process ${ }^{4}$.

\footnotetext{
${ }^{2}$ Oliver Budzinski, Pluralism of Competition Policy Paradigms and the Call for Regulatory Diversity, Philipps-University of Marburg Volkswirtschaftliche Beitraege No. 14/2003, available at SSRN: http://ssrn.com/abstract=452900, p. 3, following Adam Smith, An inquiry into the nature and causes of the wealth of nations, idem, The Theory of moral sentiments, Penguin Books, New York, 2009

${ }^{3}$ As pointed out by Stigler, Perfect Competition, Historically Contemplated, J. POL. ECON. Vol LXV, $N^{\circ} 1$, 1957, pp. 1-2, Adam Smith, aware that greater the number of agents in the market, lower the risk of collusion, conditioned competition to the knowledge by the agents of the opportunities, to freedom and to independence to act according to that knowledge and to the resources mobility, that could not be subject to limitations and must transit without barriers within the markets. Although the relationship between the prices is at this point incipient, Adam Smith, An inquiry into the nature and causes of the wealth of nations, Hackett Publishing Company, Indianapolis, 1993 , p. 28, relates the monopoly with high prices and low prices with the free market .He also sustains that monopoly is the "great enemy to good management" .Adam Smith, The Wealth of nations, Oxford University Press, Oxford, 2008, p. 149.

${ }^{4}$ Cournot, in 1838, Recherches sur les principes mathématiques de la théorie des richesses, sought to establish the relationship between the price and the number of companies in the market and endeavored to develop the rising cost rate per unit, later called marginal cost. The influence of Cournot can be seen in the work of Jevons, The theory of political economy, 1874, and Marshall, Principles of Economics, 1890.
} 
The mathematical analysis of Jevons and Walras allowed the formulation of the supply and demand general theory of equilibrium in perfect competition, later improved by $\mathrm{Knight}^{5}$ [4].

\section{PERFECT COMPETION}

Perfect competition is an economic concept that is grounded on the balance between supply and demand. In this model the amount of products that producers want to sell matches the amount of products that consumers wish to buy. The equilibrium price occurs at the level where the amount voluntarily provided is equal to the quantity sough ${ }^{6}[5]$.

This market structure demands the existence of a fairly large number of sellers and buyers. The literature called it atomism, as each buyer and seller is a small fraction of the market, acting independently and can not thus influence the price and quantities.

Products must be homogeneous and divisible, thus allowing the price varies depending on the amount. It is also requested the perfect rationality and knowledge of market by sellers and buyers.

This model assumes the existence of perfect information on market conditions in order to enable consumers to distinguish products and know the lowest price being charged in the market. Resources should be moved from one market to another without any barriers or obstacles ${ }^{7}$. The existence of barriers to entry meant the exclusion of competitors, giving rise to concentration and monopoly ${ }^{8}$.

This model also assumes the absence of externalities ${ }^{9}$.

5 .Knight, Cost of Production and Price over Long and Short Periods, J. POL. ECON, Vol 29, 1921, pp. 304-35, idem, Risk, Uncertainty, and Uncertainty, and Profit, Houghton Mifflin, Boston, 1921,pp.76-79, formulated the notion of perfect competition closer to the contemporary.

${ }^{6}$ Paul Samuelson, William Nordhaus, Economics, above cited, p.54-55.Pareto developed a concept of efficiency (Pareto efficient) in the allocation of resources according to which efficiency corresponds to the moment when it is no longer possible to rearrange the production or distribution to improve the status of any individual without making worse the situation of other person else. The efficiency is thus obtained when are no longer possible Pareto improvements (Pareto improvement).

Nicholas Kaldor: Welfare Propositions of Economics and Interpersonal Comparisons of Utility, Economic Journal, Vol 49, 1939, p. 549 and John R. Hicks, Foundations of Welfare Economics, Economic Journal, Vol 49, 1939, p. 696, sustain a less strict criterion, considering that a situation is efficient as long the persons it benefited keep interest in its implementation, even if they have to pay compensation to achieve the consent of those damaged for it.

${ }^{7}$ Resources mobility was an important contribution of John Bates Clark, The Distribution of Wealth: A Theory of Wages, Interest and Profits, 1965 to the modern concept of perfect competition, as pointed out by Stigler, Perfect competition, historically contempletad, above cited, p. 11 .

${ }^{8}$ On perfect competion requirements, see Richard Whish, Competition law, 5th edition, Lexisnexis, Butterworths, 2003, p. 6 and ff, Stigler, Perfect competition, historically contempletad, above cited, pp. 1 and ff, Stigler, The organization of industry, University of Chicago Press, 1968, pp. 5-6

9 About externalities, see Viscusi, Harrington Jr., Vernon, Economics of regulation and antitrust, $4^{\mathrm{a}}$ ed., The MIT Press, Cambridge, 2005, pp. 164165 .

Barriers to entry are one of the most controversial issues among economists, whose main contributions will be give by an economist at Harvard School, Joe Bain, who defined the entry barriers "the extent to which, in the long run, established firms can elevate their selling prices above minimal average costs
There were no transactions and enforcement costs, on the assumption premise that the parties may conclude complete contracts that courts can easily impose [6].

This model denies fraudulent and deceptive behavior and, finally, these factors should remain unchanged [7].

This concept based on the invisible hand that rules the market is limited by market failures, present in externalities and imperfect competition, resulting in phenomena such as monopoly, oligopoly and the existence of many different vendors and differentiated products.

Perfect competition, like all pure models, will prove to be therefore an ideal concept, hard to find in reality.

\section{NEOCLASSICAL PRICE THEORY}

The explanation of economic theory by mathematical models will allow analyzing the functioning of the market and building the foundations of price theory.

It has played an essential role in the discovery of the influence of marginal utility of the product, measured by the subjective value of the products, prices, by marginal utility school initially developed by Jevons, Menger and Walras, and improved, in the late nineteenth century and early twentieth century, by Joan Robinson, Pigou and Marshal, from Cambridge, under the neoclassicism [8].

In neoclassical economics, the firm is an agent whose behavior in the market was identical to that of individuals, distinguished by the fact that these maximizing wealth through the profit, while individuals maximized utilities.

Neoclassical theory considered the firm an abstraction, being focused in competition and monopoly, without studying the inner workings of the firm. The firm was exclusively orientated for the production, transforming inputs into outputs, within the firm's boundaries ${ }^{10}$.

The neoclassical firm is an autonomous entity, determined to maximize its value, which is indifferent to the shareholders will. Under neoclassical approach, the separation of ownership

of production and distribution ...without inducing potential entrants to enter the industry"(cfr. Joe Bain, Industrial Organization, 2nd ed, New York, 1968, p. 252). Stigler, The organization of industry, cit., p. 67 , advocates a narrower concept, identifying the barriers to entry with the costs that firms have to bear to enter the market, but that are not borne by firms already in the market. Scale economies and capital costs are excluded from Stigler's definition.

In both notions product differentiation is a barrier to entry, but under Stigler approach, the costs of differentiation must be higher for the new firm. Otherwise, it may be a source of economics of scale.

${ }^{10}$ Ronald H. Coase, The Institutional Structure of Production, AM. ECON. REV., Vol 82, 1992, p. 714, considered the neoclassical firm a black box The firm is a rational maximizer that responds to demand. One of the most important contributions was the analysis of the costs, with the classification of variable costs (prime costs), fixed (supplemantary costs), the importance of marginal cost and the elasticity of supply and demand. Marshall also stands out for the short and long term analysis that relates to the notion of quasirents. Marshall, Principles of Economics, pp.74-75, 323 and ff, 504 and ff..

On the abstract view of the neoclassical economics firm, see Harold Demsetz, The Theory of the Firm Revisited, J.L. ECON. \& ORG., Vol 4, 1988, p. 143 and Lionel Robbins, The Representative Firm, ECON. J., Vol 38, 1928, p. 389. 
and control of the company is understood as a principle of efficiency ${ }^{11}$ [9].

This feature is in accordance with the theory of neoclassical price rooted in the allocation of resources through operations between the rational economic agents, in a system where there is no friction, functioning perfectly.

The markets, under this approach, reflect the preferences of individuals and firm, ignoring information costs, transaction costs and externalities ${ }^{12}$.

Marshall will develop a theory of competition, in order to overcome the Cournot dilemma, affirming the compatibility between competition and economies of scale, claiming that the firm rises sustained by internal economies and asserting that during the life cycle of the firm, factors, such as, innovation and entrepreneurship, do not remain stable, leading to decreases in return, which prevent the monopolization of the market ${ }^{13}[10]$.

Marshall will introduced the concept of representative firm, a normal firm, managed with a average skills, with access to external and internal economies, with an average cycle relatively short, since the degree of enterprise, energy and ingenuity are not constant over the time [11].

Under this approach, Marshall sustained a concept of competition, different from the perfect competition, as it is accepted the existence of private markets, characterized by decreasing demand curve, based on open markets.

Neoclassical economics, through models of monopoly and oligopoly based on principles of marginal utility, will demystify the idea that perfect competition is the rule and that market failures as a monopoly, are the exception [12].

In this context, Chamberlin, The Theory of Monopolistic Competition, 1933, sustained to be possible an equilibrium in the monopolistic market, through product differentiation, since, in the absence of entry barriers, several companies produce products that sell at a slightly higher price than the marginal $\operatorname{cost}^{14}$.

${ }^{11}$ Later, the institutionalists, Adolf A. Berle, Gardiner C. Means, in their seminal work, The modern corporation \& private property, 1932, will consider the separation of control of the property responsible for the large companies and phenomena such as a monopoly and oligopoly. This matter will lead to the principal-agent theory developed in the New Economic Institutionalism

${ }^{12}$ Pigou, for the first time, in Economics of Welfare,1932, p. 183, will bring out the existence of costs of movement' of resources that later will gain prominence as transaction costs, by the work of Ronald Coase, The Nature of the Firm, Economica, Vol 4, 1937, pp. 386-400, idem, The Problem of Social Cost, JL \& ECON, Vol 3, 1, 1960, p.1-44, and Oliver Williamson, Markets and Hierarchies: Analysis and Antitrust Implications. A Study in the Economics of Internal Organization, The Free Press, New York 1975

${ }^{13}$ The Cournot's dilemma is related to the impossibility of increasing returns resulting from incompatibility between the increase of the company's efficiency and competition. Accordingly, the increase of efficiency, in particular, the decrease in the average cost of each unit produced, can give the company a dominant position in the market, excluding other market rivals, being thus incompatible with the competition.

${ }^{14}$ Chamberlin's work is contemporary of Joan Robinson 's The Economics of Imperfect Competition, 1933, who defended the monopoly is the norm and
In the 30s, the neoclassical school of marginal utility was put into question, by the ordinalist school. This school denied the comparison of marginal utility between individuals, claiming that individual preferences could not be mathematically assessed.

Hicks and Allen in The Reconsideration of the Theory of value, in 1934, will focus its analysis on consumer behavior, replacing cardinal utility, supported by the marginal utility school by ordinal utility, the consumer preferences order [13].

\section{INSTITUTIONAL ECONOMICS}

Meanwhile, it was blooming, in the United States, institutional economics, an economic approach that included economists such us Veblen, John Maurice Clark, Wesley Clair Mitchell, Walton Hamilton, Rex Tugwell and John R. Commons. Setting from the evolution of Darwin, it was studied the role of institutions in determining economic behavior, with rejection of the rational and free individual of neoclassical. As the institutional economics accepted the influence of institutions, such as, clubs, family, government, smaller economic relations, with formal and informal rules that play an important role in the movement of resources, which is no longer limited the neoclassical market, will be brought into economics ${ }^{15}[14]$.

The institutionalism will criticize the marginal utility as an economic theory of choice, questioning the absolute rationality that was recognized to humans, along with the assumption that utilities were similar in all individuals, ignoring the psychological and environmental factors that influence the choices, and the scientific capability to compare utilities. Fundamentally, under this approach, institutions should be given a broader thoughtfulness owing to the fact that it shaped individuals.

Institutional economics hostility towards the concentration of power, severely criticizing the immense power that large

that perfect competition a special case. Hovenkamp, United States Competition Policy, cit., pp. 338-339

${ }^{15}$ Coase considered himself part of this movement, as he had as main purpose to study the behavior of institutions in the real world. In The relevance of transaction costs in the economic analysis of law, "The origins of law and economics, Essays by the founding fathers," Francesco Parisi, Charles K Rowleym (eds.), The Locke Institute, Edward Elgar Publishing, Cheltenham, 2005, p.200, he regrets that economic theory consisted of "consumers without humanity, firms without organization, and even exchange without markets",

In pursuing this task, Coase has devoted many years to the study of law, as he recognized in The Nature of the Firm: Origin, JL ECON. \& ORG., Vol 4, 1988, pp.5-6. Ronald Coase is considered by some literature the father of the modern Law and Economics. Posner, The economic approach to law, Texas L Rev, Vol 53, 1975, pp. 757-782, Hovenkamp, The first great law and economics movement, Stanford L Rev, 42, No 4,1990, p. 994, idem, Coasean Markets, Eur J Law Econ, Vol 31, 2011, p. 63.

However, the marginal utility analysis that Coase applied to the institutions, in the Nature of the firm and The Problem of Social Cost, to discover what moves and limits it and the extent of its impact on the economy, will be the underpinnings of the New Institutional Economics, in particular the study of transaction costs. This movement, later developed by Oliver Williamson is one of the most influential in the economic mainstream .Cfr. Hovenkamp, Coase, Institutionalism, and the Origins of Law and Economics, above cit. p. 499 and $\mathrm{ff}$. 
firms hold in the market, is one of the distinctive features in relation to neoclassical [15].

Vertical integration, under this approach, is considered an instrument to make firms too big without efficiency advantages. This disproportionate size of firms is seen as the reason for the immunity of these firms to the competitive process, leading to monopoly and oligopoly phenomena [16].

\section{COASE AND THE NATURE OF THE FIRM}

Coase will merge neoclassical and institutional economics by applying the marginal analysis to decision-making processes of the firm, with consequences on their structure and size.

Coase, as neoclassical, treats the firm as an autonomous entity, determined to maximize its value [17].

In The nature of the firm Coase applies the marginal utility to the internal decisions of the firm, considering that the firm's decisions, including those relating to the size and integration in other markets, result from the comparison between the costs and benefits of internal production and external market.

Coase accepts that firms are intended to maximize its value, looking therefore to minimize the costs regarding the market. The firm will choose to produce the product as long as the marginal costs of internal production are lower than the marginal cost of going to the market.

Aware that either the markets or the internal production have costs, the firm, in pursuit of profit, will compare the marginal cost of production with the cost surrounding the acquisition in the market, opting for the more lucrative alternative.

In the Nature of the Firm, Coase discusses, under the name of market costs, the transaction costs, referring to costs related to the use of the market (the price mechanism) that will identify boundaries of the firm [18]

Assuming that internal production or the use of market inflicts different costs and that the firm aims at maximizing its value, the firm will compare the marginal cost inherent to the use of market or internal production.

The firm boundaries are drawn when the cost of an additional transaction within the firm exceeds the cost of performing the same transaction using the market or another firm [19].

Coase offered a marginalist explanation for the structure and size of firms, justifying, through market costs, later known as transaction costs, and the recognition of the firms commitment to maximize their value, the option of producing internally the products or resort to market ${ }^{16}$.

In this model, firms are driven by profits, through the comparison between the internal costs and the costs inherent to the market.

\footnotetext{
${ }^{16}$ Later, Coase, The Problem of Social Cost, will enlarge the boundaries of the firms to the market, through transactions costs. Hovenkamp, Harvard, Chicago and TCE, Antitrust Bull, Vol 55, № 3, 2010, p. 628.
}

Under this assumption, Coase's analysis demonstrates that, contrary to the assessment of the institutionalists, vertical integration results from the balancing of the costs to produce internally and to resort to market, denying any monopolistic purpose.

In fact, in certain situations, vertical integration may be the remedy to avoid the monopoly of the supplier of raw materials where the cost of resorting to the market is much higher than the cost to produce domestically ${ }^{17}$.

\section{CONCLUSIONS}

The Coase's genius consisted in the merger of the marginal utility school with institutionalism, applying a marginal analysis to the internal decision of the firm to answer questions relating to the size and structure of it [20].

The firm boundaries are established by the decision making procedures that favor the solution presenting greater marginal value, regardless the fact that these functions are performed within the firm or in the market.

Coase brought into economics a global approach to the firm, considering production costs, distributions costs, legal framework, among others [21].

This explanation offered by Coase will play a very important role in Chicago School of Economics and, naturally, on transaction costs economics, within the New Institutional Economics.

As this issue exceeds the scope of this paper, it must be left to another paper.

\section{REFERENCES}

[1] Paul Samuelson, William Nordhaus, Economics, 19th ed., Mcgraw-Hill International Edition, Singapore, pp. 5 e 30

[2] Oliver Budzinski, Pluralism of Competition Policy Paradigms and the Call for Regulatory Diversity, Philipps-University of Marburg Volkswirtschaftliche Beitraege No. 14/2003, disponível em SSRN: http://ssrn.com/abstract=452900, p. 4

[3] Paul Samuelson,William Nordhaus, Economics, cit., p. 30.

[4] George J. Stigler, Perfect Competition, Historically Contemplated, J. POL. ECON. Vol LXV, No 1, 1957, p. 11

[5] Paul Samuelson, William Nordhaus, Economics, above cited, pp.54-55.

[6] Wiliamson, The economic institutions of capitalism, Firms, Markets, Relational Contracting, The Free Press,New York, 1985, p. 7

[7] Knight, Risk, Uncertainty, and Profit, Boston, Houghton Mifflin, 1921, pp.78-79

[8] Richard S. Howey, The Origins of Marginalism, History of Political Economy, Vol 4, No 2, 1972, pp. 281-302.

[9] Herbert Hovenkamp, Neoclassicism and the separation of ownership and control, Virginia Law \& Business Review, Vol. 4, 2009, p. 376

[10] Alfred Marshall, Principles of Economics, above cited, pp. 266, 314, 502. Roberto Marchionatti, On the Methodological Foundations of Modern Microeconomics: Frank Knight and the "Cost Controversy" in the 1920s, History of Political Economy, Vol 35, No. 1, 2003, pp. 49-75

[11] Alfred Marshall, Principles of Economics, cit., pp. 317 ff, 459. Marchionatti, On the Methodological Foundations of Modern Microeconomics: Frank Knight and the "Cost Controversy" in the 1920s, above cited, 52.

${ }^{17}$ This position is, however, contrary to the dominant position held by Berle and Means that for many years, will influence the courts. Hovenkamp, PostChicago antitrust: a review and critique, CBLR, 2001, p.264, note 19. 
[12] Hovenkamp, United States Competition Policy in Crisis: 1890-1955, Minnesota Law Review, Vol. 94, 2009, p. 320

[13] Robert Cooter, Peter Rappoport, Were the Ordinalists Wrong About Welfare Economics. J. ECON. LIT., Vol 22, 1984, pp. 521-523.

[14] Honvenkamp. Coase, Institutionalism, and the Origins of Law and Economics, Indiana Law Journal, Vol. 86, p. 499, 2011, pp 541- 542.

[15] Hovenkamp, Coase, Institutionalism, and the Origins of Law and Economics, above cired, cit. p. 527.

[16] Hovenkamp, Enterprise and american law: 1836-1937, Harvard University Press, 1991, p. 338 .
[17] Ronald H. Coase, Nature of the Firm , Economica, New Series, Volume 4, Issue 16 (Nov., 1937), p. 404.

[18] Ronald H. Coase, Nature of the Firm ,above cited, p. 404. Hovenkamp, The Law of Vertical Integration and the Business Firm: 1880-1960, 95 Iowa Law Review 2010, p. 869.

[19] Ronald H. Coase, Nature of the Firm, above cited, ,p. 386, Herbert Hovenkamp, Coase, Institutionalism, and the Origins of Law and Economics, Indiana LJ, Vol. 86, 2011, pp. 538-539

[20] Hovenkamp, The Law of Vertical Integration and the Business Firm, 1880-1960, IOWA L. REV.,Vol 95, 2010, p. 875

[21] Hovenkamp, The law of vertical integration, above cited, p. 869. 